\title{
Flame Retardants in Furniture Foam: Benefits and Risks
}

\author{
VYTENIS BABRAUSKAS ${ }^{1}$, ARLENE BLUM ${ }^{2,3}$, REBECCA DALEY ${ }^{3}$, and LINDA BIRNBAUM ${ }^{4}$ \\ ${ }^{1}$ Fire Science and Technology Inc. \\ 9000 - 300th Place SE, Issaquah WA 98027 USA \\ ${ }^{2}$ Department of Chemistry \\ University of California Berkeley \\ Berkeley CA 94705 USA \\ ${ }^{3}$ Green Science Policy Institute \\ 1492 Olympus Avenue, Berkeley CA 94708 USA \\ ${ }^{4}$ National Cancer Institute \\ National Institutes of Health \\ Research Triangle Park NC 27709 USA
}

\begin{abstract}
The extensive use of chemical flame retardants to meet the California Furniture Flammability Standard Technical Bulletin 117 (TB117) [1] provides an example of the need for consideration of environmental impacts of fire safety interventions before they are implemented. Flame retardants are currently being used in products with high levels of human exposure without adequate toxicological testing. For example, flame retardants commercially used to meet TB117 have been found to have negative impacts upon human, animal, and environmental health [2] and notably, the TB117 standard has not been shown to have a measurable fire safety benefit. Both the unintended adverse impacts and the lack of fire safety benefits of California TB117 are discussed in detail.
\end{abstract}

KEYWORDS: flame retardants, halogens, PBDE, flammability.

\section{INTRODUCTION}

Flame retardant (FR) additives are commonly used to meet regulatory requirements mandating certain levels of fire safety performance. Even though a wide variety of FR additives have been developed, for most man-made polymers halogenated FR chemicals have been the most frequently used. This is due to their cost, availability, and extensive industry experience with this class of additives. Until recent years, only the potential benefits of their usage have been considered by regulatory bodies and not the potential drawbacks. For example, after decades of use and hundreds of studies detecting adverse health and environmental consequences, two polybrominated diphenyl ether (PBDE) commercial mixtures-PentaBDE and OctaBDEwere banned in 2003 in California and in 2004 in the European Union [3] and voluntarily withdrawn from production by the sole US manufacturer [3]. These two PBDE mixtures were subsequently listed as persistent organic pollutants (POPs) by the Stockholm Convention [4]. The cause for concern with these and other PBDEs, their replacements, and other currently used halogenated replacement chemicals is now well recognized [5].

The assumption held by much of the public, industry and scientists, is that any hazardous FR additives would be restricted from use in consumer products. However, in the United States, only chemicals in foods, drugs, and pesticides are regulated prior to reaching the marketplace. There is no requirement for health data nor sufficient authority to regulate other chemicals [6].When a number of halogenated flame retardants received detailed study, they were found to be persistent when introduced into the environment and to have serious adverse health consequences [2]. In light of these findings, it seems necessary to consider the net outcome associated with the use of FR agents, instead of only evaluating their effects on the improvement of fire safety. This could require a complex weighing of alternatives which lack a common basis for comparison, e.g., death or injury due to fire, versus damage to the environment or long-term health effects associated with direct ingestion, consumption of contaminated foodstuffs, and other modes of transfer. In some cases, however, such a complex assessment may not be needed. One example would be if there were no fire safety benefits associated with a particular usage. The use of organohalogen FRs to meet California Furniture Flammability Standard Technical Bulletin 117 (TB 117) is examined here as an example of such a case. 


\section{BENEFITS OF CALIFORNIA FURNITURE FLAMMABILITY STANDARD TB117}

The California Furniture Flammability Standard TB117 was implemented in 1975 by the California Bureau of Electronic and Appliance Repair, Home Furnishings and Thermal Insulation (the Bureau). Its avowed purpose is to reduce fire deaths and injuries associated with upholstered furniture. The standard is a smallflame ignition standard which requires polyurethane foam in juvenile products and upholstered furniture to withstand exposure to a small open flame for $12 \mathrm{~s}$ [7]. The standard also regulates smolder behavior of foams and provides fire tests for other, non-foam components. But these aspects are not of relevance to the present paper, since chemical fire retardants are not added to foams to pass the smolder test, while other components are either in very limited use or require no treatment, or both. Compliance with the standard is mandatory for all products sold in California, irrespective of where they are manufactured. Of the 50 US States, California is the only state which has such a standard. Increasingly many national furniture manufacturers are using this standard for all of their furniture sold across North America to avoid maintaining a double inventory and for defense against fire liability claims. Thus TB117 is becoming a de facto national standard, with the organohalogen flame retardants typically used to meet it being found in most furniture and baby products containing polyurethane foam sold in the US and Canada. A small-flame fire standard such as TB117 would have a fire safety benefit if a positive answer could be obtained to at least one of the two questions posed below.

\section{Do TB117 Compliant Materials Significantly Reduce the Severity of the Fire?}

The severity of a particular fuel package is quantified by its peak heat release rate (peak HRR), measured in kilowatt units [8]. Babrauskas [9] studied furniture where the peak HRR of identically-constructed furniture passing TB117 was compared to furniture made with non-fire-retardant (non-FR) foam. The differences observed between the furniture with non-FR foam and furniture made with foam complying with TB117 were within the normal data scatter from this type of test. In addition, visually the fire development over the furniture was seen to be identical. Schuhmann and Hartzell [10] also found use of TB117 foam did not reduce the peak HRR compared to non-FR foam in normal residential furniture construction. On the other hand, they found advanced foams (of much higher density and with much higher levels of flame retardants than required by TB117) did show a peak HRR about $42 \%$ lower than for TB117 foams. Similarly Babrauskas et al. [11] later also compared furniture made with non-FR foam and advanced foam, but not with TB117 foam. The advanced foam contained three different FR additives and had a density 2.5 times greater than the non-FR foam. A chair that showed $1200 \mathrm{~kW}$ peak HRR when made with non-FR foam showed a peak HRR value of approximately $50 \mathrm{~kW}$ when made with advanced FR foam. The advanced foam used was costly and not found in residential furniture, but was used to illustrate the performance achievable by incorporating state-of-the-art technology. The study concluded: "The average available escape time was more than 15-fold greater for the FR products in the room burn tests," compared to the nonFR products (113 s versus 1789 s) [12]. This statement has been distorted and improperly cited to imply that use of TB117 foams can create such a difference [12]. This is incorrect, in that the study did not examine any TB117 foams but only a costly, state-of-the-art formulation not used in residential furniture. Furthermore, the tests were carried out in fully-furnished rooms where numerous combustibles were burned and were not tests of upholstered furniture items alone. Finally, while peak HRR is the primary metric of fire hazard, time to reach peak HRR can be a useful supplemental variable, since it may reflect on the escape time available. The earlier study by Babrauskas [9] presented data showing the time-to-peak for nonFR and TB117 foams were identical, to within the data scatter of the apparatus. Thus, the answer to the first question, "Is the severity of the fire significantly reduced by the use of TB117 foam?" is clearly No.

\section{Does TB117 Foam Serve to Prevent Ignitions from Small Flame Sources?}

A severe fault of the TB117 test is that the foam alone is exposed to a small burner flame, rather than the composite piece of furniture. Under such conditions, TB117 foam with 3 to $5 \%$ of FR additive can resist a small open flame. But actual upholstered furniture always consists of a composite of at least two layers, with a fabric cover on top of foam. Furthermore, fabrics are thin membranes of about $1 \mathrm{~mm}$ that do not serve as a barrier to the flow of heat from the outside to the foam and it is common for the upholstery fabric itself to ignite from small flame sources such as a candle or a lighter. Once the fabric is burning, the foam is presented with a flame challenge which is many times larger than the cigarette lighter flame which may have originally ignited the fabric. (Note that TB117 does not consider protection from ignition by large flame sources and that it is well-established that targets which might resist a smaller flame attack may be 
unable to resist one from a larger flame [13,14]). It must additionally be noted that (a) the TB117 standard contains a separate test provision for fabrics. But this is a moot test since the procedure is the same as mandated in the Federal CS 191-53 test [15], which all fabrics sold in the US are already required to meet by the Federal government. (b) While an ostensible, but moot fabric test exists within TB117, the standard never assesses the behavior of an actual composite, i.e., a fabric on top of a layer of foam. However, the latter question has been experimentally investigated by two groups. Talley [16] tested 15 different upholstery fabrics, each over non-FR and TB117 foams of matched density $\left(24 \mathrm{~kg} \cdot \mathrm{m}^{-3}\right)$. All specimens ignited except those using one of the 15 fabrics, and for that fabric neither of the foams used led to ignition. Talley also visually observed flame spread behavior of the specimens that did ignite, and his conclusion was that "The TB117 foam made no significant, consistent difference in either ignition or flame spread." Talley also ran additional tests which showed that TB117 foams did not offer any benefit in regards to resisting smoldering ignition from cigarettes. In addition, the US Consumer Product Safety Commission (CPSC) conducted laboratory research on actual chairs and also found the test to be ineffective [17]. More broadly, as part of their regulatory mission, they undertook to determine if adopting of the TB117 standard would likely reduce deaths and injuries due to fire and concluded that "TB117 component results were not predictive of full scale performance" and that "TB117... would not, if federally mandated, ensure a substantial reduction in the risk of small open flame ignition of finished articles of furniture." Thus, the answer to the question "Does TB117 foam serve to prevent ignitions from small flame sources?" is also No.

It is important to emphasize that the above findings have not been disputed. There are no published research studies where the answer to either of the two questions is "Yes." Thus, the evaluation of the fire safety benefits of TB117 foams is simple - there are no benefits — and a public policy judgment weighing fire safety gains against health and environmental drawbacks (discussed below) is not required.

\section{HOW HAS CALIFORNIA FURNITURE FLAMMABILITY STANDARD TB117 BEEN MET?}

From its implementation in the late 1970s until 2004, TB117 was primarily met with the addition of three to five percent pentabromodiphenyl ether (pentaBDE) to the foam in furniture and juvenile products (nursing pillows, strollers, baby carriers, etc.). PentaBDE is a commercial mixture of several congeners of polybrominated diphenyl ethers (PBDE). Due to its persistence and tendency to bioaccumulate, pentaBDE has become a global contaminant and the most well studied of the brominated flame retardants.

PentaBDE and the other PBDEs are structurally similar to known human toxicants PBBs, PCBs, dioxins and furans. In addition to having similar mechanisms of toxicity in animal studies [18], PBDEs similarly persist and bioaccumulate in humans and animals [19]. In 1999 and 2001, $98 \%$ [20] and $95 \%$ [21], respectively, of the usage of pentaBDE, was in North America, in large part to meet TB117. PentaBDE was banned in California in 2003 due to its persistence and toxicity; eight other states and the European Union (EU) followed suit. In 2004, Chemtura, (previously Great Lakes Chemical), the sole US manufacturer, voluntarily ceased production. In 2009 pentaBDE was listed as a persistent organic pollutant under the Stockholm Convention [22]. However pentaBDE continues to be a global pollutant, moving from reservoirs in furniture and other products into the biota.

\section{HEALTH EFFECTS OF PENTABDE}

Halogenated flame retardants, including PBDEs, have been associated with cancer, immune and endocrine disruption, and reproductive and neurodevelopmental effects in humans and a variety of animal species [2].

\section{Effects of PentaBDE on Laboratory Animals}

A large body of experimental data, both in vivo and in vitro, shows that pentaBDE can disrupt the endocrine system in mammals, birds, and fish, resulting in effects on thyroid, ovarian, and androgen function $[23,24]$. PentaBDE also disrupts thyroid hormone homeostasis which can cause neurologic impairments, including a reduction in the IQ of offspring [25,26].

Many of these effects result from exposure during prenatal or neonatal development [25,27]. Such effects include impacts on gene expression of liver enzymes [28,29] endocrine disruption (altered thyroid hormone levels) [30], reproductive damage [31-33], immunotoxicity [34,35], and neurotoxic effects [36]. Experiments conducted by Eriksson and co-workers in mice developmentally exposed either to penta- or higher BDEs [37-40] during the period of rapid brain growth have shown neurotoxic effects, including impair- 
ment of spontaneous behavior, cholinergic transmitter susceptibility, and habituation capability. The deficits in learning and memory were observed to persist into adulthood and worsen with age. The developmental effects of PBDEs are exacerbated by co-exposure to PCBs in rats [41].

As an endocrine disruptor, pentaBDE exposure results in increased lypolysis and reduced insulinstimulated metabolism in rat adipocytes [42], effects which have been associated with obesity, insulin resistance, and Type 2 diabetes. PentaBDE is also anti-androgenic [43,44].

\section{Exposure and Health Impacts of PentaBDE on Humans}

A wide range of adverse effects in humans associated with pentaBDE exposure include developmental, endocrine, thyroid, reproductive and neurological effects, as well as diabetes [25,45,46].

\section{Exposure}

Halogenated flame retardants such as pentaBDE and its replacements are a predominant class of toxic chemicals found in human biomonitoring studies [47]. The importance of house dust as a major exposure route for pentaBDE in humans has been studied [49,51]. Human external exposure from dust, diet, and air and the resulting internal exposure to pentaBDE has been recently reviewed $[48,49]$. About $20 \%$ of exposure to PBDEs in Americans is currently estimated to derive from diet, with the highest exposure from butter, seafood, and meat [50]. The remaining $80 \%$ of exposure is assumed to come mainly from the ingestion and inhalation of PBDE-contaminated dust [51].

The PBDE concentrations in the North American general population are 10 to 40-times higher than the concentrations reported for populations in Europe and other parts of the world [52-55]. A positive correlation between pentaBDE concentrations in house dust and breast milk has been shown [56]. In California, populations have been shown to be disproportionately exposed to pentaBDE, likely due to the state's fire regulation TB117 that has led to high usage of halogenated flame retardants in furniture and baby products [47]. A recent study found that body burden levels in California children are two to nine times higher than in similaraged children across the US, and four to nine times higher than children in Mexico, and up to one hundred times higher than those in children of similar ages in Europe [57].

\section{Developmental Effects}

Exposure to pentaBDE in umbilical cord blood is associated with adverse neurodevelopmental effects in children [58]. Children in the highest $20 \%$ of the exposure distribution showed lower IQ performance scores (ranging from 5 to 8 points lower) at all ages [58]. In the Netherlands, prenatal exposure to pentaPBDE was associated with significant adverse effects on motor, cognitive, and behavioral outcomes in the children [59]. PentaBDE congeners appear to affect the development of fetal human neural progenitor cells via endocrine disruption of cellular thyroid hormone signaling [60]. These studies are the first to suggest a biological mechanism for in vivo studies reporting behavioral and IQ effects after developmental exposures.

In addition to their prenatal exposures, after birth young children are exposed at higher levels than adults from breast milk and ingestion of dust due to hand-to-mouth contact [61,62]. It has been estimated that a breastfed infant in the US would be exposed to $1500 \mathrm{ng} / \mathrm{day}$ of PBDEs [63]. Accordingly, the highest serum levels of PBDEs are found in infants and toddlers, most vulnerable to developmental toxics $[64,65]$.

\section{Reproductive Effects}

Harley et al. reported an association between pentaBDE exposure and reduced fertility in women from a predominantly Mexican-immigrant community in California [46]. Increasing serum levels of pentaBDE were significantly associated with longer time to pregnancy. Prenatal exposure of the infants of these women was associated with low birth weight, altered cognitive behavior, and significantly reduced plasma levels of thyroid stimulating hormone (TSH) [46]. Another study reported that elevated levels of pentaBDE in breast milk of pregnant Taiwanese women were associated with adverse birth outcomes including decreased weight, length, and chest circumference of their infants [66]. The effects were observed at levels lower than the average pentaBDE levels in the adult US population.

Elevated pentaBDE levels in breast milk were correlated with cryptorchidism (undescended testicles) in the sons of mother-son pairs studied in Denmark and Finland [67]. The levels associated with cryptorchidism were also positively correlated with serum lutenizing hormone (LH) concentrations in the infants, which 
suggested a possible compensatory mechanism to achieve normal testosterone levels. This observation is consistent with the anti-androgenic effects of PBDEs observed in experimental animals. A pilot study conducted by Japanese researchers reported that elevated blood levels of BDE-153 were correlated with decreased sperm count and decreased testes size [68].

A recent study in the US reported a relationship between altered hormone levels in men and pentaBDE levels in house dust [69]. The findings included significant inverse associations between PBDEs in house dust and serum concentrations of the free androgen index, $\mathrm{LH}$, and follicle-stimulating hormone (FSH) and positive associations between pentaBDE and sex-hormone binding globulin (SHBG) and free $\mathrm{T}_{4}$.

\section{Thyroid Effects}

Turyk et al. reported an association between pentaBDE and elevated $\mathrm{T}_{4}$ levels and thyroglobulin antibodies in the blood of adult male consumers of Great Lakes sport fish [70]. The effects were observed at pentaBDE levels comparable to those found in the general US population and were independent of PCB exposure and sport fish consumption. A recent study of Inuit adults [71] reported that plasma concentrations of BDE47 were related to increasing total $\mathrm{T}_{3}$ levels.

\section{Endocrine Disruption}

As endocrine-disruptors, some PBDEs are reported to cause disturbances in glucose and lipid metabolism in rat adipose tissue, which is characteristic of metabolic obesity and Type 2 diabetes [42], but few studies have examined the relationships between PBDEs and diabetes in humans. Turyk et al. reported a nonsignificant association between PBDE exposure and diabetes in Great Lakes sport fish consumers with hypothyroid disease [72,70]. A recent study in US adults examined the association between diabetes and PBDEs [73]. The serum concentrations of the hexa-BDE congener -153 were significantly related to metabolic syndrome and diabetes prevalence at background concentrations, suggesting that PBDEs may contribute to diabetes in the general population.

\section{Carcinogenic Effects}

The carcinogenic potential of PBDEs has not yet been adequately addressed in animal or human studies. Part of the observed increase in thyroid cancer rates in the U.S. is hypothesized to be related to the increasing population exposure to pentaBDE and other thyroid hormone disrupting compounds [28]. A study by Hardell et al. [74] reported an association between BDE-47 concentrations and an increased risk for nonHodgkin's lymphoma (NHL). In the highest risk/highest exposure group, BDE-47 was significantly correlated with elevated titers to Epstein Barr IgG, a herpes virus that associated with certain subgroups of NHL.

\section{Effects of PentaBDE on Wildlife}

Because of the usage of pentaBDE in North America to comply with TB117, the levels found in wildlife are increasing in a variety of species of fish, birds, and marine mammals as well as humans [75-78].

Fish

Recent studies have shown that PBDE exposure may affect thyroid hormone homeostasis, sperm production, disease resistance and neurodevelopment in fish [34,79]. Plasma $\mathrm{T}_{4}$ levels were significantly reduced in juvenile lake trout exposed to 13 PBDE congeners at levels somewhat higher than those found in the environment [80]. In male fathead minnows, repeated oral exposure to BDE-47 reduced sperm production [81]. Low-dose embryonic exposure of killifish to a pentaBDE mixture resulted in neuro-behavioral effects and a subtle developmental asymmetry with respect to tail curvature direction, with a J-shaped doseresponse curve suggestive of thyroid hormone disruption [82]. Similarly, exposure of zebrafish embryos to high doses of BDE-47 resulted in developmental effects, including morphological, cardiac, and neural deficits that impaired later survivorship in the fish larvae [83]. Chronic exposure of juvenile zebrafish to ecologically relevant levels of BDE-47 resulted in altered locomotion behavior [79]. A recent study showed that dietary exposure of juvenile Chinook salmon to environmentally relevant concentrations of PBDEs increased susceptibility to pathogenic micro-organisms [34].

Birds

PBDEs are detected at high concentrations in birds of prey, such as peregrine falcons and common kestrels. Recent studies have shown PBDE-related endocrine-disrupting and reproductive effects at environmentally 
relevant concentrations. In captive American kestrels, Fernie et al. [84] reported decreased plasma $T_{4}$ and vitamin A levels, as well as indications of oxidative stress in kestrels dosed with environmentally relevant levels of the pentaBDE mixture DE-71. DE-71 exposure also had a negative impact on the timing and frequency of courtship [85]. Exposure to DE-71 resulted in delayed egg laying, reduced egg size, eggshell thinning, and reduced fertility and reproductive success in kestrels and falcons [86,87]. Fernie et al. [86] concluded that these changes in the reproductive success of captive kestrels, particularly eggshell thinning, may partially explain the decline of American kestrels across North America. McKernan et al. [88] reported decreased pipping and hatching success in American kestrel embryos following the air cell injection of DE71. Similarly, Johansson et al. [86] reported a negative relationship between PBDEs and reproductive success in peregrine falcons from Sweden. PBDE concentrations in eggs were negatively related to the average number of young produced from individual breeding females over a 2-7 year period. Van den Steen et al. [89] observed negative effects of PBDEs on reproductive performance in European starlings. A field study in the US [90] reported a negative relationship between reproductive performance and PBDEs in eggs of wild ospreys at two locations in the highly contaminated Columbia River valley of Oregon and Washington. North American osprey populations may be at risk for contaminant-induced reproductive impairment.

\section{Marine mammals}

Marine mammals accumulate extremely high concentrations of pentaBDE and other persistent organic pollutants through feeding on contaminated prey. Adult animals are exposed through the consumption of contaminated fish and young animals are exposed to PBDEs in utero and in breast milk. Marine mammals from the California coast contain the highest reported pentaBDE levels on record. These include adult male sea lions [91] and transient killer whales off the California coast, as well as in resident killer whales from the Puget Sound-Strait of Georgia Basin [92,93]. Along the US Atlantic coast, relatively high pentaBDE concentrations were reported in young harbor seals [94] and in juvenile bottlenose dolphins [95].

Studies have shown that co-exposure to pentaBDE and PCBs is associated with thyroid hormone alterations in gray seals [96] and harbor seals [97], and with thymic atrophy and splenic depletion in harbor porpoises from the North and Baltic Seas [98]. A study of infectious diseases in California sea otters co-exposed to PCBs and pentaBDE also suggested possible synergistic interactions between these contaminant groups [99]. However, a recent study reported that in grey seals, levels of PBDEs alone significantly reduced the probability of first year survival [100].

\section{CHEMICAL REPLACEMENTS FOR PENTABDE}

After pentaBDE was phased out in 2004, a major replacement used for TB117 compliance was Firemaster 550, also produced by Chemtura, a mixture of four flame retardant chemicals whose composition was a trade secret. In 2004, the EPA Design for the Environment predicted reproductive, neurological, and developmental toxicity and persistent degradation products for the brominated components of Firemaster 550 [101]. In 2005, Chemtura agreed to conduct reproductive and developmental toxicity and migration studies by January 2009. Data provided by Chemtura in November 2008 have recently been evaluated by the EPA. Firemaster 550 components include: (1) triphenyl phosphate which is known to be eco-toxic, (2) Triaryl phosphate isopropylated which is a probable reproductive toxin, (3) Bis (2-ethylhexyl) tetrabromophthalate, and (4) 2-ethylhexyl-2,3,4,5-tetrabromobenzoate [102]. The brominated components have been found in dust [102], sewage sludge [103], marine mammals [104], and seven species in the Arctic [105]. Firemaster 600, described by Chemtura as having a trade-secret composition, is another pentaBDE replacement.

TDCPP or chlorinated tris is also a widely used replacement flame retardant for pentaBDE in polyurethane foam. It is produced by Israeli Chemicals, Limited (ICL) under the trade name Fyrol and by Albermarle under the trade name Antiblaze. Recent studies show TDCPP, like pentaBDE and Firemaster 550 components, can migrate from foam products into indoor house dust [106]. These semi-volatile compounds can form thin films on walls and windows [107]. The inhalation and ingestion of contaminated dust has been shown to be a major route of human exposure, especially for children [106].

\section{EXPOSURE AND HEALTH EFFECTS OF PENTABDE REPLACEMENTS}

Few studies have been conducted on the health effects of these replacement chemicals in animals or humans. The brominated Firemaster 550 components TBB and TBPH are genotoxic in fish, causing increased DNA strand breaks in orally exposed fish [108]. Triphenyl phosphate (TPP) is toxic to aquatic organisms including 
Daphnia [109], rainbow trout, and fathead minnows [110]. Triaryl phosphate isopropylated is a reproductive/developmental toxin at mid- to high doses in rats [101,110]. Histopathologic changes were observed in female reproductive organs and adrenals at all doses.

TDCPP, or chlorinated Tris, was removed from use in children's pajamas in 1978 due to its mutagenicity and has subsequently been found to be a probable human carcinogen in a study at the US Consumer Product Safety Commission (CPSC) [111]. The CPSC report estimates the lifetime cancer risk from tris-treated furniture foam is up to 300 cancer cases/million and their chronic hazard guidelines define a substance as hazardous if lifetime cancer risk exceeds one in a million. TDCPP is also absorbed by humans [112]. The US EPA considers TDCPP a moderate hazard for cancer and reproductive/developmental effects [113].

A recent study showed that men living in homes with high amounts of the organophosphate flame retardants TPP and TDCPP in house-hold dust had reduced sperm counts and altered levels of hormones related to fertility and thyroid function [114]. High levels of TPP in dust were associated with a substantial reduction of sperm concentrations and an increase in prolactin levels. Increased prolactin is considered a marker of decreased neuroendocrine/dopamine activity and also may be associated with erectile dysfunction [115]. High levels of TDCPP in dust were associated with a $17 \%$ increase in prolactin and a $3 \%$ decline in free thyroid hormone levels. The possible synergistic or additive effects of the numerous flame retardant chemicals in use have not been studied in animals or humans.

\section{CONCLUSIONS}

Since 1975, hundreds of millions of kilograms of pentaBDE and its replacements which include TDCPP and Firemaster 500 have been used to meet California TB117. A fire safety benefit has not been established. Research suggests that this standard should be reevaluated in light of the fire science and health information discussed above. Prior to implementing new flammability standards, decision makers should evaluate the potential fire safety benefit as well as the health and environmental impacts of the chemicals, materials, or technologies likely to be used. Special scrutiny should be given to small open-flame standards that are likely to be met by adding organohalogen flame retardants to foam or plastic in consumer products.

\section{ACKNOWLEDGMENTS}

The authors wish to thank many colleagues whose expertise in science and policy has informed this article: Susan Shaw, Kannan Kurunthachalam, David Rich, Don Lucas, Catherine Koshland, Dina Dobraca, Roland Weber, Alex Madonik, Michael Kirschner, Raphael Shannon, Ann Stein. We also thank Sarah Hanson, Michelle Berger, Eileen Kramer, Peter Brigham, and Nickilou Krigbaum, for their assistance.

Disclaimer: The research described in this article has been reviewed by the National Institute of Environmental Health Sciences, and approved for publication. Approval does not signify that the contents necessarily reflect the views of the Agency, nor does the mention of trade names or commercial products constitute endorsement or recommendation for use.

\section{REFERENCES}

[1] Technical Bulletin 117-Requirements, Test Procedure and Apparatus for Testing the Flame Retardance of Resilient Filling Materials Used in Upholstered Furniture, State of California, Bureau of Home Furnishings and Thermal Insulation, West Highlands CA (current edition is 2000).

[2] Shaw, S.D., Blum, A., Weber, R., Kannan, K., Rich, D., Lucas, D., Koshland, C.P., Dobraca, D., Hanson, S., and Birnbaum, L.S., (2010); Halogenated flame retardants: Do the fire safety benefits justify the risks? Reviews on Environmental Health 25(4): 261-305.

[3] Great Lakes Chemical. Thanks to New Product Technology, Great Lakes Chemical Corporation Announces That It Will Cease Production of Penta-PBDE Flame Retardant by end of 2004. [accessed 1 February 2011]. http://www.pu2pu.com/htdocs/Customers/greatlakes/Firemaster.htm

[4] Stockholm Convention Secretariat. What are POPs? 2010. [accessed 1 February 2011]. Available: http://chm.pops.int/Convention/The\%20POPs/tabid/673/language/en-US/Default.aspx

[5] Digangi, J., Blum, A., Bergman, A., de Wit, C.A., Lucas, D., Mortimer, D., Schecter, A., Scheringer, M., Shaw, S.D., and Webster, T.F., (2010); San Antonio Statement on brominated and chlo- 
rinated flame retardants. Environ Health Persp. 118(12): A516-518, http://dx.doi.org/10.1289/ehp.1003089

[6] Wilson, M.P., and Schwarzman, M. R., Green Chemistry: Cornerstone to a Sustainable California, The Centers for Occupational and Environmental Health, University of California (2008).

[7] Damant, G.H., (1981) California Upholstered Furniture Combustibility Standard: 1981 Update, J. Consumer Product Flammability 8:209-220.

[8] Babrauskas, V., and Peacock, R.D., (1992); Heat Release Rate: The Single Most Important Variable in Fire Hazard, Fire Safety J. 18: 255-272, http://dx.doi.org/10.1016/0379-7112(92)90019-9

[9] Babrauskas, V., (1983) Upholstered Furniture Heat Release Rates: Measurements and Estimation, J. Fire Sciences 1:9-32, http://dx.doi.org/10.1177/073490418300100103

[10] Schuhmann, J.G., and Hartzell, G.E., (1989) Flaming Combustion Characteristics of Upholstered Furniture, J. Fire Sciences 7:368-402, http://dx.doi.org/10.1177/073490418900700602

[11] Babrauskas, V., Harris, R.H., Jr., Gann, R.G., Levin, B.C., Lee, B.T., Peacock, R.D., Paabo, M., Twilley, W., Yoklavich, M.F., and Clark, H.M., Fire Hazard Comparison of Fire-Retarded and Non-Fire-Retarded Products (Spec. Publ. SP 749), [US] Natl. Bur. Stand., Gaithersburg MD (1988).

[12] Flame Retardants and Fire Safety fact sheet, BSEF, [accessed February 11 2011] available: http://www.bsef.com/fire-safety-benefits/flame-retardants-fire-safety/

[13] Dembsey, N.A., and Williamson, R.B., (1993) Effect of Ignition Source Exposure and Specimen Configuration on the Fire Growth Characteristics of a Combustible Interior Finish Material, Fire Safety J. 21:313-330, http://dx.doi.org/10.1016/0379-7112(93)90019-M

[14] Babrauskas, V., Ignition Handbook, Fire Science Publishers, Issaquah WA (2003).

[15] Standard for the Flammability of Clothing Textiles (CS 191-53), Code of Federal Regulations (16 CFR 1610), Government Printing Office.

[16] Talley, T.H., Phases 1\&2, UFAC Small Open Flame Tests and Cigarette Ignition Tests, Annual AFMA Flammability Conf. (1995).

[17] Medford, R.L., and Ray, D.R., Upholstered Furniture Flammability: Fires Ignited by Small Open Flames and Cigarettes, US CPSC, Washington DC (Oct. 24, 1997).

[18] Birnbaum L.S., Staskal D.F., and Diliberto J.J., (2003) Health effects of polybrominated dibenzop-dioxins (PBDDs) and dibenzofurans (PBDFs), Environment International 29(6): 855, http://dx.doi.org/10.1016/S0160-4120(03)00106-5

[19] Hites R.A. (2004) Polybrominated Diphenyl Ethers in the Environment and in People: A MetaAnalysis of Concentrations, Environ Sci Technol 38(4):945, http://dx.doi.org/10.1021/es035082g

[20] Hale R.C., Alaee M., Manchester-Neesvig J.B., Stapleton H.M., and Ikonomou M.G. (2003) Polybrominated diphenyl ether flame retardants in the North American environment, Environment International 19: 771, http://dx.doi.org/10.1016/S0160-4120(03)00113-2

[21] Major Brominated Flame Retardants Volume Estimates, BSEF 2003.

[22] Stockholm Convention on Persistent Organic Pollutants. [Accessed 11 February 2011] Available: http://chm.pops.int/

[23] Darnerud P.O., (2008) Brominated flame retardants as possible endocrine disrupters. Int J Androl 31:152-60, http://dx.doi.org/10.1111/j.1365-2605.2008.00869.x

[24] Legler J., (2008) New insights into the endocrine disrupting effects of brominated flame retardants. Chemosphere 73:216-22, http://dx.doi.org/10.1016/j.chemosphere.2008.04.081

[25] Birnbaum L.S., and Staskal D.F., (2004) Brominated flame retardants: Cause for concern? Environ Health Persp 112:9-17, http://dx.doi.org/10.1289/ehp.6559 
[26] Costa L.G., and Giordano G., (2007) Developmental neurotoxicity of polybrominated diphenyl $\begin{array}{lllll}\text { ether } & \text { (PBDE) flame } & \text { retardants. NeuroToxicology }\end{array}$ http://dx.doi.org/10.1016/j.neuro.2007.08.007

[27] Shaw S.D., Kannan K., (2009) Polybrominated diphenyl ethers in marine ecosystems of the American continents: Foresight from current knowledge. Rev Environ Health 24:157-229, http://dx.doi.org/10.1515/REVEH.2009.24.3.157

[28] Lundgren M., Darnerud P.O., Molin Y., Lilienthal H., Blomberg J., and Ilbäck N.-G., (2007) Viral infection and PBDE exposure interact on CYP gene expression and enzyme activities in the mouse liver, Toxicology 242:100-8, http://dx.doi.org/10.1016/j.tox.2007.09.014

[29] Szabo D.T., Richardson V.M., Ross D.G., Diliberto J.J., Kodavanti P.R.S., and Birnbaum L.S., (2009) Effects of perinatal PBDE exposure on hepatic phase I, phase II, phase III, and deiodinase 1 gene expression involved in thyroid hormone metabolism in male rat pups, Toxicol Sci 107:2739, http://dx.doi.org/10.1093/toxsci/kfn230

[30] Kuriyama S.N., Wanner A., Fidalgo-Neto A.A., Talsness C.E., Koerner W., and Chahoud I. (2007) Developmental exposure to low-dose PBDE-99: Tissue distribution and thyroid hormone levels. Toxicology 242:80-90, http://dx.doi.org/10.1016/j.tox.2007.09.011

[31] Lilienthal H., Hack A., Roth-Härer A., Grande S.W., and Talsness C.E., (2006) Effects of developmental exposure to $2,2^{\prime}, 4,4^{\prime}, 5$-pentabromodiphenyl ether (PBDE-99) on sex steroids, sexual development, and sexually dimorphic behavior in rats, Environ Health Persp. 114:194-201, http://dx.doi.org/10.1289/ehp.8391

[32] McDonald T., (2005) Polybrominated diphenyl ether levels among United States residents: Daily intake and risk of harm to the developing brain and reproductive organs, Integr Env Assess Manage 1:343-54, http://dx.doi.org/10.1002/ieam.5630010404

[33] Talsness C.E., Kuriyama S.N., Sterner-Kock A., Schnitker P., Grande S.W., Shakibael M., Andrade A., Grote K., and Chahoud I., (2008) In utero and lactational exposures to low doses of polybrominated diphenyl ether- 47 alter the reproductive system and thyroid gland of female rat offspring, Environ Health Persp 116:308-14, http://dx.doi.org/10.1289/ehp.10536

[34] Arkoosh M.R., Boylen D., Dietrich J., Anulacion B.F., Ylitalo G.M., Bravo C.F., Johnson L.L., Loge F.J., and Collier T.K., (2010) Disease susceptibility of salmon exposed to polybrominated diphenyl ethers (PBDEs), Aquat Toxicol 98:51-9, http://dx.doi.org/10.1016/j.aquatox.2010.01.013

[35] Martin P.A., Mayne G.J., Bursian S.J., Tomy G.T., Palace V.P., Pekarik C., and Smits J., (2007) Immunotoxicity of the commercial polybrominated diphenyl ether mixture DE-71 in ranch mink (Mustela vision), Environ Toxicol Chem 26:988-97, http://dx.doi.org/10.1897/06-246R.1

[36] Eriksson P., Jakobsson E., and Fredriksson A., (2001) Brominated flame retardants: A novel class of developmental neurotoxicants in our environment? Environ Health Persp 109:903-8, http://dx.doi.org/10.1289/ehp.01109903

[37] Viberg H., Fredriksson A., Jakobsson E., Orn U., and Eriksson P., (2003) Neurobehavioral derangements in adult mice receiving decabrominated diphenyl ether (PBDE 209) during a defined period of neonatal brain development, Toxicol Sci 76:112-20, http://dx.doi.org/10.1093/toxsci/kfg210

[38] Viberg H., Fredriksson A, and Eriksson P. Neonatal exposure to polybrominated diphenyl ether (PBDE 153) disrupts spontaneous behaviour, impairs learning and memory, and decreases hippocampal cholinergic receptors in adult mice, Toxicol Appl Pharm 192:95-106

[39] Viberg H., Fredriksson A., and Eriksson P., (2004) Neonatal exposure to the brominated flameretardant, 2,2',4,4',5-pentabromodiphenyl ether, decreases cholinergic nicotinic receptors in hippocampus and affects spontaneous behaviour in the adult mouse, Environ Toxicol Pharm 17:61-5, http://dx.doi.org/10.1016/j.etap.2004.02.004

[40] Viberg H., Johansson N., Fredriksson A., Eriksson J., Marsh G., and Eriksson P., (2006) Neonatal exposure to higher brominated diphenyl ethers, hepta-, octa-, or nonabromodiphenyl ether, impairs 
spontaneous behavior and learning and memory functions of adult mice, Toxicol Sci 92:211-8, http://dx.doi.org/10.1093/toxsci/kfj196

[41] He P., Wang A.G., Xia T., Gao P., Niu Q., Guo L.J., and Chen X.M., (2009) Mechanisms underlying the developmental neurotoxic effect of PBDE-47 and the enhanced toxicity associated with its combination with PCB153 in rats, Neurotoxicology 30:1088-95, http://dx.doi.org/10.1016/j.neuro.2009.06.005

[42] Hoppe A.A., and Carey G.B., (2007) Polybrominated diphenyl ethers as endocrine disruptors of adipocyte metabolism, Obesity 15:2942-50, http://dx.doi.org/10.1038/oby.2007.351

[43] Stoker T.E., Laws S.C., Crofton K.M., Hedge J.M., Ferrell J.M., and Cooper R.L., (2004) Assessment of DE-71, a commercial polybrominated diphenyl ether (PBDE) mixture, in the EDSP male and female pubertal protocols, Toxicol Sci 78:144-55, http://dx.doi.org/10.1093/toxsci/kfh029

[44] Stoker T.E., Cooper R.L., Lambright C.S., Wilson V.S., Furr J., and Gray L.E. (2005) In vivo and in vitro anti-androgenic effects of DE-71, a commercial polybrominated diphenyl ether (PBDE) mixture, Toxicol Appl Pharm 207:78-88, http://dx.doi.org/10.1016/j.taap.2005.05.010

[45] Lim J.-S., Lee D.-H., and Jacobs D.R.J., (2008) Association of brominated flame retardants with diabetes and metabolic syndrome in the U.S. population, 2003-2004, Diabetes Care 31:1802-7, http://dx.doi.org/10.2337/dc08-0850

[46] Harley K.G., Chevrier J., Bradman A., Sjodin A., Eskenazi B., (2009) Associations between maternal PBDE serum concentrations and birth weight and duration of gestation, Organohalogen Compd 71:2251

[47] Zota A.R., Rudel R.A., Morello-Frosch R.A., and Brody J.G., (2008) Elevated house dust and serum concentrations of PBDEs in California: Unintended consequences of furniture flammability standards? Environ Sci Technol 42:8158-64, http://dx.doi.org/10.1021/es801792z

[48] Frederiksen M., Vorkamp K., Thomsen M., and Knudsen L.E., (2009) Human internal and external exposure to PBDEs - A review of levels and sources, Int J Hyg Envir Heal 212:109-34, http://dx.doi.org/10.1016/j.ijheh.2008.04.005

[49] Johnson-Restrepo B., and Kannan K., (2009) An assessment of sources and pathways of human exposure to polybrominated diphenyl ethers in the United States, Chemosphere 76:542-8, http://dx.doi.org/10.1016/j.chemosphere.2009.02.068

[50] Schecter A., Harris T.R., Shah N., Musumba A., and Päpke O., (2008) Brominated flame retardants in US food, Mol Nutr Food Res 52:266-72, http://dx.doi.org/10.1002/mnfr.200700166

[51] Lorber M., (2008) Exposure of Americans to polybrominated diphenyl ethers, J Expo Sci Env Epid 18:2-19, http://dx.doi.org/10.1038/sj.jes.7500572

[52] Johnson-Restrepo B., Kannan K., Rapaport D., and Rodan B., (2005) Polybrominated diphenyl ethers and polychlorinated biphenyls in human adipose tissue from New York, Environ Sci Technol 39:8243-50, http://dx.doi.org/10.1021/es051551y

[53] Kalantzi O.I., Brown F.R., Caleffi M., Goth-Goldstein R., and Petreas M., (2009) Polybrominated diphenyl ethers and polychlorinated biphenyls in human breast adipose samples from Brazil, Environ Int 35:113-7, http://dx.doi.org/10.1016/j.envint.2008.09.008

[54] Pérez-Maldonado I.N., Ramírez-Jiménez M.D.R., Martínez-Arévalo L.P., López-Guzmán O.D., Athanasiadou M., Bergman Å., Yarto-Ramírez M., Gavilán-García A., Yáñez L., and DíazBarriga F., (2009) Exposure assessment of polybrominated diphenyl ethers (PBDEs) in Mexican children, Chemosphere 75:1215-20, http://dx.doi.org/10.1016/j.chemosphere.2009.01.083

[55] Sjödin A., Päpke O., McGahee E.E., Focant J.-F., Jones R.S., Pless-Mulloli T., Toms L.-M.L., Herrmann T., Müller J., Needham L.L., and Patterson Jr D.G., (2008) Concentration of polybrominated diphenyl ethers (PBDEs) in household dust from various countries, Chemosphere 73:S131-6, http://dx.doi.org/10.1016/j.chemosphere.2007.08.075 
[56] Wu N., Herrmann T., Paepke O., Tickner J., Hale R., Harvey E., La Guardia M., McClean M.D., and Webster T.F., (2007) Human exposure to PBDEs: Associations of PBDE body burdens with food consumption and house dust concentrations, Environ Sci Technol 41:1584-9, http://dx.doi.org/10.1021/es0620282

[57] Rose M., Bennett D.H., Bergman Å., Fangstrom B.F., Pessah I.N., and Hertz-Picciotto I., (2010) PBDEs in 2-5 year-old children from California and associations with diet and indoor environment, Environ Sci Technol 44:2648-53, http://dx.doi.org/10.1021/es903240g

[58] Herbstman J.B., Sjodin A., Kurzon M., Lederman S.A., Jones R.S., Rauh V., Needham L.L., Tang D., Niedzwiecki M., Wang R.Y., and Perera F., (2010) Prenatal exposure to PBDEs and neurodevelopment, Environ Health Persp 118:712-9, http://dx.doi.org/10.1289/ehp.0901340

[59] Roze E., Meijer L., Bakker A., Van Braeckel K.N.J.A., Sauer P.J.J., and Bos A.F., (2009) Prenatal exposure to organohalogens, including brominated flame retardants, influences motor, cognitive, and behavioral performance at school age, Environ Health Persp 117:1953-8

[60] Schreiber T., Gassmann K., Götz C., Hübenthal U., Moors M., Krause G., Merk H.F., Crofton K.M., Nguyen N.-H., Scanlan T.S., Abel J., Rose C.R., and Fritsche E., (2010) Polybrominated diphenyl ethers induce developmental neurotoxicity in a human in vitro model: Evidence for endocrine disruption, Environ Health Persp 118:572-8, http://dx.doi.org/10.1289/ehp.0901435

[61] Fischer D., Hooper K., Athanasiadou M., Athanassiadis I., and Bergman A., (2006) Children show highest levels of polybrominated diphenyl ethers in California family of four: a case study, Environ Health Perspect. 114(10): 1581-1584, http://dx.doi.org/10.1289/ehp.8554

[62] Johnson-Restrepo B., and Kannan K., (2009) An assessment of sources and pathways of human exposure to polybrominated diphenyl ethers in the United States, Chemosphere 76(4): 542-548, http://dx.doi.org/10.1016/j.chemosphere.2009.02.068

[63] Schecter A., Päpke O., Harris T.R., Tung K.C, (2006) Partitioning of polybrominated diphenyl ether (PBDE) congeners in human blood and milk, Toxicol Environ Chem. 88(2): 319-324, http://dx.doi.org/10.1080/02772240600605087

[64] Lunder S., and Jacob A. Fire Retardants in Toddlers and Their Mothers. [Accessed 4 September 2008] Available: http://www.ewg.org/node/26900

[65] Toms L.M., Harden F., Paepke O., Hobson P., Ryan J.J., and Mueller J.F., (2008) Higher accumulation of polybrominated diphenyl ethers in infants than in adults, Environ. Sci. Technol. 42(19): 7510-5, http://dx.doi.org/10.1021/es800719v

[66] Chao H.-R., Wang S.-L., Lee W.-J., Wang Y.-F., Päpke O., (2007) Levels of polybrominated diphenyl ethers (PBDEs) in breast milk from central Taiwan and their relation to infant birth outcome and maternal menstruation effects, Environ Int 33:239-45, http://dx.doi.org/10.1016/j.envint.2006.09.013

[67] Main K.M., Kiviranta H., Virtanen H.E., Sundqvist E., Tuomisto J.T., Tuomisto J., Vartiainen T., Skakebaek N.E., Toppari J., (2007) Flame retardants in placenta and breast milk and cryptorchidism in newborn boys. Environ Health Persp 115:1519-26

[68] Akutsu K., Takatori S., Nozawa S., Yoshiike M., Nakazawa H., Hayakawa K., Makino T., and Iwamoto T., (2008) Polybrominated diphenyl ethers in human serum and sperm quality, B Environ Contam Tox 80:345-50, http://dx.doi.org/10.1007/s00128-008-9370-4

[69] Meeker J.D., Johnson P.I., Camann D., Hauser R., (2009) Polybrominated diphenyl ether (PBDE) concentrations in house dust are related to hormone levels in men, Sci Total Environ 407:3425-9, http://dx.doi.org/10.1016/j.scitotenv.2009.01.030

[70] Turyk M.E., Persky V.W., Imm P., Knobeloch L., Chatterton R.J., Anderson H.A., (2008) Hormone disruption by PBDEs in adult male sport fish consumers, Environ Health Persp 116:163541, http://dx.doi.org/10.1289/ehp.11707 
[71] Dallaire R., Dewailly E., Pereg D., Dery S., Ayotte P., (2009) Thyroid function and plasma concentrations of polyhalogenated compounds in Inuit adults, Environ Health Persp 117:1380-6

[72] Turyk M.E., Persky V.W., Imm P., Knobeloch L., Chatterton R.J., and Anderson H.A., (2008) Hormone disruption by PBDEs in adult male sport fish consumers. Environ Health Persp 116:1635-41, http://dx.doi.org/10.1289/ehp.11707

[73] Lim J.-S., Lee D.-H., and Jacobs D.R.J., (2008) Association of brominated flame retardants with diabetes and metabolic syndrome in the U.S. population, 2003-2004, Diabetes Care 31:1802-7, http://dx.doi.org/10.2337/dc08-0850

[74] Hardell L., Eriksson M., Lindstrom G., Van Bavel B., Linde A., Carlberg M., and Liljegren G., (2001) Case-control study on concentrations of organohalogen compounds and titers of antibodies to Epstein-Barr virus antigens in the etiology of non-Hodgkin lymphoma, Leuk Lymph 42:619-29, http://dx.doi.org/10.3109/10428190109099322

[75] Elliott J.E., Wilson L.K., and Wakeford B., (2005) Polybrominated diphenyl ether trends in eggs of marine and freshwater birds from British Columbia, Canada, 1979-2002, Environ Sci Technol 39:5584-91, http://dx.doi.org/10.1021/es050496q

[76] Ikonomou M.G., Rayne S., and Addison R.F., (2002) Exponential increases of the brominated flame retardants, polybrominated diphenyl ethers, in the Canadian arctic from 1981 to 2000, Environ Sci Technol 36:1886-92, http://dx.doi.org/10.1021/es011401x

[77] Johnson-Restrepo B., Kannan K., Addink R., and Adams D.H., (2005) Polybrominated diphenyl ethers and polychlorinated biphenyls in a marine foodweb of coastal Florida, Environ Sci Technol 39:8243-50, http://dx.doi.org/10.1021/es051551y

[78] Ross P.S., Couillard C.M., Ikonomou M.G., Johannessen S.C., Lebeuf M., Macdonald R.W., and Tomy G.T., (2009) Large and growing environmental reservoirs of Deca-BDE present an emerging health risk for fish and marine mammals, Mar Pollut Bull 58:7-10, http://dx.doi.org/10.1016/j.marpolbul.2008.09.002

[79] Chou C.-T., Hsiao Y.-C., Ko F.-C., Cheng J.-O., Cheng Y.-M., Chen T.-H., (2010) Chronic exposure of 2,2',4,4'-tetrabromodiphenyl ether (PBDE-47) alters locomotion behavior in juvenile zebrafish (Danio rerio), Aquat Toxicol 98:388-95, http://dx.doi.org/10.1016/j.aquatox.2010.03.012

[80] Tomy G.T., Palace V.P., Halldorson T., Braekevelt E., Danell R., Wautier K., Evans B., Brinkworth L., and Fisk A.T., (2004) Bioaccumulation, biotransformation, and biochemical effects of brominated diphenyl ethers in juvenile lake trout (Salvelinus namaycush), Environ Sci Technol 38:1496-1504, http://dx.doi.org/10.1021/es035070v

[81] Muirhead E.K., Skillman A.D., Hook S.E., Schultz I.R., (2006) Oral exposure of PBDE-47 in fish: Toxicokinetics and reproductive effects in Japanese medaka (Oryzias latipes) and fathead minnows (Pimephales promelas), Environ Sci Technol 40:523-8, http://dx.doi.org/10.1021/es0513178

[82] Timme-Laragy A.R., Levin E.D., Di Giulio R.T., (2006) Developmental and behavioral effects of embryonic exposure to the polybrominated diphenylether mixture DE-71 in the killifish (Fundulus heteroclitus), Chemosphere 62:1097-1104, http://dx.doi.org/10.1016/j.chemosphere.2005.05.037

[83] Lema S.C., Schultz I.R., Scholz N.L., Incardona J.P., and Swanson P., (2007) Neural defects and cardiac arrhythmia in fish larvae following embryonic exposure to 2,2',4,4'-tetrabromodiphenyl ether (PBDE 47), Aquat Toxicol 82:296-307, http://dx.doi.org/10.1016/j.aquatox.2007.03.002

[84] Fernie K.J., Shutt J.L., Mayne G.J., Hoffman D., Letcher R.J., Drouillard K.G., and Ritchie I.J., (2005) Exposure to polybrominated diphenyl ethers (PBDEs): Changes in thyroid, vitamin a, glutathione homeostasis, and oxidative stress in American kestrels (Falco sparverius), Toxicol Sci 88:375-83, http://dx.doi.org/10.1093/toxsci/kfi295

[85] Fernie K.J., Shutt J.L., Letcher R.J., Ritchie J.I., Sullivan K., and Bird D.M., (2008) Changes in reproductive courtship behaviors of adult American kestrels (Falco sparverius) exposed to environmentally relevant levels of the polybrominated diphenyl ether mixture, DE-71, Toxicol Sci 102:171-8, http://dx.doi.org/10.1093/toxsci/kfm295 
[86] Johansson A.K., Sellstrom U., Lindberg P., Bignert A., and de Wit C.A., (2009) Polybrominated diphenyl ether congener patterns, hexabromocyclododecane, and brominated biphenyl 153 in eggs of peregrine falcons (Falco peregrinus) breeding in Sweden, Environ Toxicol Chem 28:9-17, http://dx.doi.org/10.1897/08-142.1

[87] Fernie K.J., Shutt J.L., Letcher R.J., Ritchie I.J., and Bird D.M., (2009) Environmentally relevant concentrations of DE-71 and HBCD alter eggshell thickness and reproductive success of American kestrels, Environ Sci Technol 43:2124-30, http://dx.doi.org/10.1021/es8027346

[88] McKernan M.A., Rattner B.A., Hale R.C., and Ottinger M.A., (2009) Toxicity of polybrominated diphenyl ethers (DE-71) in chicken (Gallus gallus), mallard (Anas platyrhynchos), and American kestrel (Falco sparverius) embryos and hatchlings, Environ Toxicol Chem 28:1007-12, http://dx.doi.org/10.1897/08-318.1

[89] Van den Steen E., Eens M., Covaci A., Dirtu A.C., Jaspers V.L.B., Neels H., and Pinxten R., (2009) An exposure study with polybrominated diphenyl ethers (PBDEs) in female European starlings (Sturnus vulgaris): Toxicokinetics and reproductive effects, Environ Pollut 157:430-6, http://dx.doi.org/10.1016/j.envpol.2008.09.031

[90] Henny C.J., Kaiser J.L., Grove R.A., Johnson B.L., and Letcher R.J., (2009) Polybrominated diphenyl ether flame retardants in eggs may reduce reproductive success of ospreys in Oregon and Washington, USA, Ecotoxicology 18:802-13, http://dx.doi.org/10.1007/s10646-009-0323-4

[91] Meng X.-Z., Blasius M.E., Gossett R.W., and Maruya K.A., (2009) Polybrominated diphenyl ethers in pinnipeds stranded along the southern California coast, Environ Pollut 157:2731-6, http://dx.doi.org/10.1016/j.envpol.2009.04.029

[92] Krahn M.M., Hanson M.B., Baird R.W., Boyer R.H., Burrows D.G., Emmons C.K., Ford J.K.B., Jones L.L., Noren D.P., Ross P.S., Schorr G.S., and Collier T.K., (2007) Persistent organic pollutants and stable isotopes in biopsy samples (2004/2006) from Southern Resident killer whales, Mar Pollut Bull 54:1903-11, http://dx.doi.org/10.1016/j.marpolbul.2007.08.015

[93] Rayne S., Ikonomou M.G., Ross P.S., Ellis G.M., and Barrett-Lennard L.G., (2004) PBDEs, PBB, and PCNs in three communities of free-ranging killer whales (Orcinus orca) from the northeastern Pacific ocean, Environ Sci Technol 39:4293-9, http://dx.doi.org/10.1021/es0495011

[94] Shaw S.D., Berger M.L., Brenner D., Carpenter D.O., Tao L., Hong C.-S., and Kannan K., (2008) Polybrominated diphenyl ethers (PBDEs) in farmed and wild salmon marketed in the Northeastern United States, Chemosphere 71:1422-31, http://dx.doi.org/10.1016/j.chemosphere.2008.01.030

[95] Fair P.A., Mitchum G.B., Hulsey T.C., Adams J., Zolman E.S., McFee W., Wirth E., and Bossart G.D., (2007) Polybrominated diphenyl ethers (PBDEs) in blubber of free-ranging bottlenose dolphins (Tursiops truncatus) from two southeast Atlantic estuarine areas, Arch Environ Con Tox 53:483-94, http://dx.doi.org/10.1007/s00244-006-0244-7

[96] Hall A.J., Kalantzi O.I., and Thomas G.O., (2003) Polybrominated diphenyl ethers (PBDEs) in grey seals during their first year of life - are they thyroid hormone endocrine disruptors? Environ Pollut 126:29-37, http://dx.doi.org/10.1016/S0269-7491(03)00149-0

[97] Hall A.J., and Thomas G.O., (2007) Polychlorinated biphenyls, DDT, polybrominated diphenyl ethers and organic pesticides in United Kingdom harbor seals (Phoca vitulina)-mixed exposures and thyroid homeostasis, Environ Toxicol Chem 26:851-61, http://dx.doi.org/10.1897/06-310R.1

[98] Beineke A., Siebert U., McLachlan M., Bruhn R., Thron K., Failing K., Müller G., and Baumgärtner W., (2005) Investigations of the potential influence of environmental contaminants on the thymus and spleen of harbor porpoises (Phocoena phocoena), Environ Sci Technol 39:3933-8, http://dx.doi.org/10.1021/es048709j

[99] Kannan K., Perrotta E., Thomas N.J., and Aldous K.M., (2007) A comparative analysis of polybrominated diphenyl ethers and polychlorinated biphenyls in southern sea otters that died of infectious diseases and noninfectious causes, Arch Environ Con Tox 53:293-302, http://dx.doi.org/10.1007/s00244-006-0251-8 
[100] Hall A.J., Thomas G.O., and McConnell B.J., (2009) Exposure to persistent organic pollutants and first-year survival probability in gray seal pups, Environ Sci Technol 43:6364-9, http://dx.doi.org/10.1021/es9004398

[101] EPA, Furniture Flame Retardancy Partnership: Environmental Profiles of Chemical FlameRetardant Alternatives for Low-Density Polyurethane Foam (EPA 742-R-05-002A, September, 2005), pp. 4-2 to 4-5.

[102] Stapleton H.M., Allen J.G., Kelly S.M., Konstantinov A., Klosterhaus S., Watkins D., McClean M.D., and Webster T.F., (2008) Environ Sci Technol 42(18): 6910, http://dx.doi.org/10.1021/es801070p

[103] Klosterhaus S., Konstantinov A., and Stapleton, H. M. Presentation at the $10^{\text {th }}$ Annual Workshop on Brominated Flame Retardants. Victoria, British Columbia, Canada. 2008.

[104] Lam J.C.W., Lau R.K.F., Murphy M.B., and Lam P.K.S., (2009) Temporal Trends of Hexabromocyclododecanes (HBCDs) and Polybrominated Diphenyl Ethers (PBDEs) and Detection of Two Novel Flame Retardants in Marine Mammals from Hong Kong, South China, Environ Sci Technol. 43:6944-6949, http://dx.doi.org/10.1021/es901408t

[105] Sagerup K., Hertzke D., Harju M., Evenset A., Christensen G.N., Routti H., Fuglei E., Aars J., Strom H., and Gabrielsen G.W., (2010) New brominated flame retardants in Arctic biota, Sci. Total Environ. 408: 2885-2918, http://dx.doi.org/10.1016/j.scitotenv.2009.08.037

[106] Stapleton H.M., Klosterhaus S., Eagle S., Fuh J., Meeker J.D., Blum A., and Webster T.F., (2009) Detection of organophosphate flame retardants in furniture foam and U.S. house dust, Environ Sci Technol 43:7490-5, http://dx.doi.org/10.1021/es9014019

[107] Weschler C.J., and Nazaroff W.W., (2008) Semivolatile organic compounds in indoor environments, Atmos Environ 42: 9018-40, http://dx.doi.org/10.1016/j.atmosenv.2008.09.052

[108] Bearr J.S., Stapleton H.M., and Mitchelmore C.L., (2010) Accumulation and DNA damage in fathead minnows (Pimephales promelas) exposed to 2 brominated flame-retardant mixtures, Firemaster 550 and Firemaster BZ-54, Environ Toxicol Chem 29:722-9, http://dx.doi.org/10.1002/etc.94

[109] Lin K., (2009) Joint acute toxicity of tributyl phosphate and triphenyl phosphate to Daphnia magna, Environ Chem Lett 7:309-12, http://dx.doi.org/10.1007/s10311-008-0170-1

[110] Chemtura. Material Safety Data Sheet \#694, Product: Durad 150. 2006, http://www.chemtura.com

[111] Babich, M. A. CPSC Staff Preliminary Risk Assessment of Flame Retardant (FR) Chemicals in Upholstered Furniture Foam. 2006.

[112] Hudec T., Thean J., Kuehl D., and Dougherty R.C., (1981) Tris(dichloropropyl)phosphate, a mutagenic flame retardant: frequent occurrence in human seminal plasma, Science 211:951-2, http://dx.doi.org/10.1126/science.7466368

[113] US Environmental Protection Agency (US EPA). Furniture flame retardancy partnership: Environmental profiles of chemical flame-retardant alternatives for low-density polyurethane foam. 2005, http://www.epa.gov/dfe/pubs/index.htm

[114] Meeker J.D., Stapleton H.M., (2010) House dust concentrations of organophosphate flame retardants in relation to hormone levels and semen quality parameters, Environ Health Persp 118:31823, http://dx.doi.org/10.1289/ehp.0901332

[115] Betts, K., (2010) Endocrine Damper? Flame retardants linked to male hormone, sperm count changes, Environ Health Persp 118(3):A130, http://dx.doi.org/10.1289/ehp.118-a130b 